Мирюгін В.І., Даниленко О.В., Магу О.М., Горбань Г.В., Заріцький М.В. Державний науково-дослідний інститут випробувань і сертифікації озброєння та військової техніки

\title{
ЗАСТОСУВАННЯ НАПІВАКТИВНИХ РАДІОЛОКАЦІЙНИХ СИСТЕМ (У ПОЛІ ПІДСВІЧУВАННЯ СТОРОННІХ ДЖЕРЕЛ) ДЛЯ ВИКОНАННЯ ЗАВДАНЬ РОЗВІДКИ ПОВІТРЯНОГО ПРОСТОРУ
}

\begin{abstract}
У статті розглянута можливість використання сигналів покриття мережі інтернет, стільникових телефонних мереж, сигналів радіомовлення та телебачення для забезпечення виявлення повітряних цілей. Розглянуто переваги, недоліки, склад та принцип роботи напівактивної радіолокаційної ситеми. Досліджені питання технічної реалізації антен та приймачів напівактивної радіолокаційної системи. Запропоновано алгоритм обробки сигналів у напівактивній радіолокаційній системі. Доповнення системи радіолокаційної розвідки повітряного простору засобами напівактивної радіолокаџії забезпечить ї̈ скритність, а відповідно й живучість.
\end{abstract}

Ключові слова: радіолокаџія, напівактивна радіолокаційна система, обробка сигналів, виявлення цілей, принциип роботи, антена, приймач, передавач.

\section{Постановка проблеми}

На теперішній час, однією з проблем у зоні проведення Операції Об’єднаних Сил є ведення розвідки противником за допомогою БпЛА та здійснення коригування вогню ворожої артилерії. Проблематичним залишається вдосконалення системи ППО та ведення радіолокаційної розвідки, отже, основним недоліком активної радіолокаційної системи $є$ простота розвідки іiі позицій противником. Підвищення ефективності ведення радіолокаційної розвідки можливе шляхом доповнення системи ППО засобами напівактивної радіолокації.

\section{Аналіз останніх досліджень і публікацій}

Радіолокація, як область науки i техніки, поєднує методи та технічні засоби виявлення, вимірювання координат, параметрів руху та деяких інших характеристик об'єктів локації $[1,2]$. Радіолокація базується на використанні радіохвиль, які випромінюються, ретранслюються або розсіюються об'єктами. За способом використання випромінювання, радіолокацію зазвичай поділяють на активну та пасивну. Активні радіолокаційні (РЛ) системи випромінюють у простір електромагнітну енергію та виявляють відбиті від цілей сигнали. В основу пасивної радіолокації покладено реєстрацію сигналів, що випроміюються самими цілями.

3 середини 1970-х років почав розвиватися такий напрям радіолокації, як напівактивна радіолокація. Її принцип полягає в тому, що на приймальній позиції реєструються сигнали, відбиті від цілі, які випромінювалися не власним передавачем РЛ системи, а деяким зовнішнім по відношенню до системи передавачем. Сигнали такого передавача називають сигналами підсвічування. Найчастіше в якості підсвічування, використовують сигнали мовних (радіо- та телевізійних) передавачів, стільникових телефонних мереж, супутникових навігаційних систем, мережі інтернет тощо.

Напівактивна радіолокація поєднує ідеї пасивної та активної локації, а саме відсутній власний передавач, але при цьому виявлення цілі відбувається при обробці прийнятих відбитих сигналів. Окрім того, що в напівактивній системі природнім чином реалізується просторове рознесення передавача та приймача, вона являє собою різновид бістатичної РЛ системи, отже, до неї може застосовуватися вся теорія бістатичної локації. Основні переваги та недоліки напівактивної радіолокації пов'язані з відсутністю в ії складі власного передавача. Перевагами $\epsilon$ : менша вартість виробництва, розміщення та експлуатація виробів, відсутність необхідності виділення частотного ресурсу, відсутність 
шкідливого впливу на зовнішнє середовище, відсутність постановки завад іншим радіотехнічним пристроям. Окрім того, перевагою є можливість формування довільної зони виявлення, за рахунок широкої мережі достатньо потужних передавачів підсвічування та оптимального вибору місцезнаходження приймальної позиції.

До недоліків можна віднести відсутність контролю за передавачем: його місце знаходження, тип сигналу, режим роботи (режим роботи не залежить від РЛ системи і не може бути налаштований в інтересах локаційної системи, окрім випадків, коли в якості джерела сигналу підсвічування використовується передавач, який схожий на звичайний мовленний, але в реальності погоджений 3 приймальною позицією напівактивної радіолокаційної ситеми). До того ж, реалізація принципів напівактивної радіолокації $\epsilon$ технологічно складною та потребує використання особливого обладнання та високоефективних алгоритмів обробки. Але з розвитком наземного цифрового мовлення використання даної технології має свої переваги для вирішення задач радіолокації.

\section{Виклад основного матеріалу}

Майже на всій території України наявне покриття мережі інтернет (IEEE 802.11(Wi-Fi)), IEEE 802.16 (WiMax)), стільникових телефонних мереж GSM 900 та 1800 МГц, системи радіомовлення та телебачення (DVB-S, DVB-T(T2), DVB-M, T-DAB) тощо [3-5]. Всі вони функціонують у діапазоні ультракоротких хвиль (УКХ, або FMдіапазон). Чим ширший спектр сигналів, що використовуються, тим більше класифікаційних ознак цілі в спектральній області можна отримати за допомогою пасивної радіолокації. Достовірність отриманої інформації залежить від відповідності характеристик сигналів та параметрів приймального пристрою. Отже, чим ширший діапазон частот зондуючого сигналу, тим більш повну та точну інформацію про повітряну ціль можна отримати.

Найбільший ефект багаточастотної радіолокації досягається при статистичній незалежності сигналів, що відповідають різноманітним несучим частотам. Фізично це можна пояснити тим, що відповідні їм максимуми діаграм вторинного випромінювання цілі зсунуті відносно один одного. Це призводить до зменшення урізання сумарної діаграми вторинного випромінювання та відносної величини флюктуацій відбитого сигналу, завдяки чому збільшуються дальність дії засобів радіолокації та надійність виявлення повітряних цілей.

Необхідною, але недостатньою умовою статистичної незалежності відбитих сигналів $€$ ортогональність відповідних складових зондуючого сигналу. Це повязано з тим, що при відбитті сигналу від поверхні змінюється поляризація поля хвилі. Поляризація відбитої хвилі залежить від діелектричних параметрів матеріалу поверхні. Окрім того, при відбитті сигналу збільшується ширина його спектру, в якому з'являються комбінаційні складові, а також 3'являються або придушуються парні (непарні) гармоніки сигналу. У багатопроменевому каналі, окрім прямого променя, енергія надходить на вхід приймача ще кількома траєкторіями, при цьому відбиті сигнали відстають за часом від прямого сигналу та мають меншу амплітуду (за рахунок розсіювання та зміни поляризації). Розсіяне об'єктом поле можна розглядати, як векторну суму напруженості полів його локальних центрів розсіювання. Перетворення Фур'є по осі частот перетворює іiі в синограму. Синограма - це трьохмірний графік у декартовій системі координат залежності амплітуди відбитого від об'єкту сигналу від відносної дальності та кута опромінення.

3 метою виявлення цілей з малою доплерівською складовою, в районах де відсутній мобільний зв'язок, ефірне телебачення, тощо, можуть використовуватися автономні переносні передавальні пристрої, які працюють за визначеною програмою та використовують надкороткі мікрохвильові імпульси. Окрім згаданого вище слід відмітити, що параметри переносних передавальних пристроїв можна відносно просто змінювати, змінюючи характеристики генератора. Отже, у стаціонарних РЛ пристроях може використовуватися лінійка стандартних генераторів, які налаштовані на різні частоти 3 різними параметрами імпульсів, що дозволить оперативно змінювати характеристики зондуючих імпульсів безпосередньо під час роботи станції. 
Інформація, яка використовується для селекції та розпізнавання цілі, міститься в сукупності РЛ сигналів, що приймаються. Але найчастіше для селекції та розпізнавання цілі використовують певні виміряні ознаки цілі, які порівнюють у відповідності до алгоритмів розпізнавання 3 відомими (еталонними) ознаками. Для стійкої роботи приймального пристрою необхідно мати зразки відбитих сигналів мобільного зв'язку, радіостанцій та радіосигналу бездротової мережі стандарту IEEE $802.11 \mathrm{~b} / \mathrm{g}$ від різних типів цілей.

Розглянемо склад та принцип роботи напівактивної РЛ системи.

Напівактивна РЛ система у загальному випадку складається з декількох рознесених у просторі передавальних і приймальних позицій, та поділяється на бістатичні (один приймач та один передавач) та мультистатичні (декілька приймачів-один передавач, декілька передавачів - один приймач, декілька передавачів - декілька приймачів).

Мультистатичні навіактивні РЛ системи можуть бути одночастотними (тобто, приймати сигнали від декількох передавачів, які працюють на одній частоті) та багаточастотними. Відмінністю когерентних систем є наявність двох каналів приймання прямого та відбитого від цілі сигналів. У системі вимірюється часовий інтервал між надходженням цих сигналів, що, в свою чергу, дозволяє визначити просторові координати цілі, за умови, якщо на приймальній позиції здійснюється вимірювання напрямку польоту цілі. Особливістю обробки сигналу пасивної когерентної РЛ системи є розрахунок взаємної функції кореляції прямого та відбитого сигналів.

Некогерентним напівактивним РЛ системам для вимірювання координат цілі необхідно не менше двох приймальних позицій при пеленгаційному та не менше трьох приймальних позицій при різницево-дальномірному способах визначення координат. Окрім дальності та напрямку напівактивна РЛ ситема вимірює бістатичний доплерівський зсув частоти відбитого сигналу. Сукупність всіх вимірювань дозволяє визначити координати, курс та швидкість цілі. При використанні в системі декількох передавачів або приймачів, наявність декількох бістатичних вимірювань може суттєво покращити результуючу точність. У мультистатичній напівактивній РЛ ситемі за наявності синхронних вимірювань декількома приймальними позиціями можливе одномоментне вимірювання повного вектору швидкості цілі. Потенційні характеристики напівактивної РЛ системи суттєво залежать від виду сигналу, що використовується, а саме - від структури його функції невизначеності.

Розглянемо основні джерела випромінювання, які можна використовувати для підсвічування цілей у напівактивній радіолокаційній системі.

FM- та УКВ-випромінення (частоти 66...108 МГц). Передавачі розташовуються на мачтах або баштах. Антени випромінюють по азимуту на $360^{\circ}$, але не випромінюють вгору. Передавачі розташовані в основному в міських і приміських зонах. У цих місцях приймальні позиції напівактивних РЛ систем можуть використовувати сигнали декількох передавачів достатньої потужності.

Аналогове телебачення (частоти до 500...600 МГц). Ширина смуги сигналу 8 МГц при цьому вона має порізаний характер, окремо передаються: відеосигнал, сигнал кольоровості, аналогове аудіо, цифрове аудіо. Ширина смуги відеосигналу 5,5 МГц. Антени випромінюють вниз по азимуту на $360^{\circ}$. Присутня невизначеність вимірювання дальності, яка обумовлена періодом передачі ліній зображення та складає 9,6 км.

Стільникові телефонні мережі. Мережі стандарту GSM працюють на частоті 900 МГц i 1800 МГц. Ширина смуги сигналу 25 МГц, для окремої станції, поділена на 125 FDMA-каналів по 200 кГц. Таким чином роздільна здатність при використанні стільникових мереж гірша, ніж при використанні телевізійних сигналів. Окрім того сектор випромінювання антен стільникового зв'язку складає $120^{\circ}$. Випромінення спрямоване донизу. Мачти рознесені на 10 км. Основна тенденція розвитку - встановлювати передавачі меншої потужності, але частіше.

DRM (Digital Radio Mondiale)- багатофункціональна система цифрового радіомовлення, яка призначена для застосування в діапазонах частот до 30 МГц. У системі DRM передбачено використання каналів, які займають смуги частот 4,5; 5; 9; 10; 18; 20 кГц. 
Смуга 20 кГц відповідає роздільній здатності по бістатичній дальності 15 км. Короткі хвилі DRM-випромінення мають здатність загоризонтного розповсюдження: за допомогою рефракції - через іоносферу на відстань $800 \ldots 3000$ км при одному відбитті від іоносфери та за допомогою дифракції - вздовж земної поверхні.

Отже, багатопозиційна напівактивна РЛ система дозволяє більш точно визначати координати цілей, за один вимір оцінити вектор швидкості цілі та об'єднати переваги різних типів сигналу підсвічування.

При виборі оптимального місця розташування приймальної позиції напівактивної РЛ системи можна використовувати різноманітні критерії оптимізації: максимізувати співвідношення сигнал/шум, точність вимірювання дальності (яка залежить від взаємного розташування приймача, передавача і повітряної цілі), точність вимірювання швидкості (яка крім взаємного розташування передавальних та приймальних станцій залежить також від напрямку руху цілі) тощо.

3 метою технічної реалізації антен та приймачів у радіолокаційних засобах, які використовуються для ведення радіолокаційної розвідки в Збройних Силах України необхідно виконати наступні вимоги побудови та алгоритми обробки сигналів.

Схема побудови когеретної напівактивної РЛ системи потребує наявності двох каналів приймання, для прямого та відбитого сигналу. Отже, приймальна позиція повинна мати два приймальних канали та пристрій спільної обробки інформації. Оскільки прямий сигнал достатньо потужний, а напрямок на передавач заздалегідь відомий, антена в цьому каналі може бути всебічно направленою. Стосовно антени в каналі відбитого сигналу треба зауважити, що вона повинна бути вузьконаправленою та скануючою або багатопроміневою. Основним завданням, яке потребує вирішення у напівактивній РЛ системі, є виявлення слабких відбитих від цілі сигналів на фоні потужного прямого і відбитих сигналів від поверхні та місцевих предметів (селекція рухомих цілей). Вирішення цієї проблеми потребує вживання наступних заходів:

- розміщення антени канала відбитого сигналу в області затінювання прямого сигналу за допомогою рельєфу місцевості та споруд;

- електродинамічне екранування прямого сигналу;

- поляризаційна режекція прямого сигналу (при відбитті сигналу від цілі відбувається деполяризація та кросполяризація, при прийманні тільки кросполяризаційної складової сигналу енергетичні втрати становлять близько 3 дБ, а послаблення прямого сигналу досягає значення приблизно 10 дБ);

- використання приймачів з великим динамічним діапазоном;

- формування під час просторово-часової обробки нуля діаграми направленості в напрямку на передавач;

- спектрально-часова режекція прямого сигналу при когерентній обробці перевідбитого сигналу.

На теперішній час типовим для напівактивної РЛ системи $\epsilon$ застосування багатоелемнтних (8..16 елементів) антенних решіток, із синтезованою цифровим способом діаграмою направленості та багатоканальних цифрових приймачів. Останнім часом з'являються схеми антенних систем, у яких одна антена виконана у вигляді двомірного масива випромінювачів, що забезпечує приймання прямого та відбитого сигналів із вимірюванням азимута та кута місця цілі. Важливою частиною напівактивної РЛ системи $€$ пристрій обробки сигналів, напрямком розвитку якого $є$ перехід до повністю цифрового локатору.

Під час цифрової обробки сигналів мають виконуватися наступні дії:

- оцифровування сигналів на несучій частоті;

- цифрове формування діаграми направленості-сигнали всіх антен піддаються ваговому сумуванню $з$ метою отримання одного проміня для прямого сигналу та декількох променів для відбитих; 
- декодування прямого сигналу та його повторне кодування 3 метою отримання еталонної копії сигналу передавача без шумів та спотворень; сигналу;

- усунення небажаних копій прямого сигналу, що надходить 3 каналу відбитого

- розрахунок взаємної функції невизначеності прямого та відбитого сигналів;

- аналіз взаємної функції невизначеності з метою виявлення цілей;

- оцінка параметрів сигналу (вимірювання бістатичних затримки та доплерівського зміщення частоти, азимуту та кута місця);

- оцінка положення та швидкості цілі за допомогою отриманих значень параметрів сигналу та відомих координат передавача підсвічування;

- розрахунок повного вектора швидкості та інших параметрів руху цілі під час іiі супроводження.

\section{Висновки}

Для виконання завдань 3 контролю використання повітряного простору та своєчасного приведення сил та засобів системи протиповітряної оборони у вищий ступінь бойової готовноті при виявленні засобів повітряного нападу та повітряної розвідки противника, на теперішній час у зоні проведення Операції Об'єднаних Сил розгорнута система радіолокаційної розвідки (СРЛР) повітряного простору, основу якої складають традиційні засоби активної радіолокації.

Основним недоліком такої системи є іï низька живучість, що обумовлено наявністю випромінюваних сигналів, а відповідно й простотою розвідки позицій радіолокаційних засобів противником. Забезпечення скритності, а відповідно й живучості СРЛР повітряного простору можливо шляхом іiі доповнення засобами напівактивної радіолокації. Тим більше, що в зоні проведдення Операції Об'єднаних Сил продовжує функціонувати розгалуджена система радіотехнічних засобів, які можуть забезпечити поле підсвічування.

Доповнення СРЛР технічними засобами напівактивної радіолокації дозволить своєчасно виявляти противника та здійснювати оповіщення сил та засобів системи протиповітряної оборони із забезпеченням скритності СРЛР.

\section{СПИСОК ЛІТЕРАТУРИ}

1. Радиоэлектронные системы. Основы построения и теория: справочник; под ред. Я.Д. Ширмана / Я.Д. Ширман, С.Т. Багдасарян, А.С. Маляренко. - М.: Радиотехника, 2007. $512 \mathrm{c}$.

2. Skolnik M. Radar handbook / M. Skolnik. - The McGraw-Hill Companies, 2008. - [3-rdEd.]. $-1351 \mathrm{p}$.

3. Каппович П.И. Анализ методов электронной компенсации опорного сигнала в целевом канале полуактивного когерентного бистатического DVB-T2 радара / П.И. Каппович, С.А. Кореневский, В.В. Муравьев // Доклады Белорусского государственного университета информатики и радиоэлектроники. - Минск: БГУИР, 2019. - №5(123) - С. 52-59.

4. Борисенков А.В. Радиолокатор с синтезированной апертурой, паразитирующий на сигналах телевизионного вещания / А.В. Борисенков, О.В. Горячкин, В.Н. Долгополов, Б.Г. Женгуров // Вестник Самарского государственного аэрокосмического университета. - Самара: СГАКУ, 2014. - №2(44). - С. 38-46.

5. Гриб Д.А. Про можливість створення комбінованого активно-пасивного мало висотного радіолокаційного поля при використанні кільцевих активних фазованих антенних решіток / Д.А. Гриб, В.О. Тютюнник // Наука і техніка Повітряних Сил Збройних Сил України. - Х.: ХУПС, 2014. - №2(15) - С. 101-106. 


\section{Мирюгін Владислав Ігорович}

науковий співробітник - інженер-випробувач Державного науково-дослідного інституту випробувань i сертифікації озброєння та військової техніки, Чернігів, Україна https://orcid.org/0000-0003-3511-6612 +38073-063-01-63

\section{Даниленко Олександр Володимирович} старший науковий співробітник-старший інженер-випробувач Державного науководослідного інституту випробувань i сертифікації озброєння та військової техніки, Чернігів, Україна

https://orcid.org/0000-0002-9246-6574

+38093-424-48-79

\section{Магу Олексій Миколайович}

начальник науково-дослідного

Державного науково-дослідного інституту випробувань i сертифікації озброєння та військової техніки, Чернігів, Україна https://orcid.org/0000-0002-2557-8664 +38067-309-81-87

\section{Горбань Геннадій Валентинович} молодший науковий співробітник - інженер Державного науково-дослідного інституту випробувань i сертифікації озброєння та військової техніки, Чернігів, Україна https://orcid.org/0000-0001-6766-511X +38095-111-98-61

Заріцький Микола Васильович молодший науковий співробітник Державного науководослідного інституту випробувань i сертифікації озброєння та військової техніки, Чернігів, Україна https://orcid.org/0000-0003-0933-9038

\section{Vladislav Miriugin}

Researcher of State Scientific Research Institute of Armament and Military Equipment Testing and Certification, Chernihiv, Ukraine https://orcid.org/0000-0003-3511-6612 +38073-063-01-63

\section{Oleksandr Danylenko}

Senior Researcher of State Scientific Research Institute of Armament and Military Equipment Testing and Certification, Chernihiv, Ukraine https://orcid.org/0000-0002-9246-6574 $+38093-424-48-79$

\section{Alexey Magu}

Chief of Section of State Scientific Research Institute of Armament and Military Equipment Testing and Certification, Chernihiv, Ukraine https://orcid.org/0000-0002-2557-8664 +38067-309-81-87

\section{Hennadii Horban}

Junior Researcher - engineer of State Scientific Research Institute of Armament and Military Equipment Testing and Certification, Chernihiv, Ukraine https://orcid.org/0000-0001-6766-511X +38095-111-98-61

\section{Nickolai Zaritskii}

Junior Researcher of State Scientific Research Institute of Armament and Military Equipment Testing and Certification, Chernihiv, Ukraine https://orcid.org/0000-0003-0933-9038

\section{THE USE OF SEMI-ACTIVE RADAR SYSTEMS (IN THE ILLUMINATION TARGET ELECTROMAGNETIC FIELD OF EXTERIOR LIGHT SOURCE) FOR FULFILLING THE TASKS OF AIR SURVEILLANCE \\ V. Miriugin, O. Danylenko, A. Magu, H. Horban, N. Zaritskii}

The article deals with the possibility of using signals of the Internet coverage, cell-phone networks, radio and television signals to provide detection of air targets. The advantages, disadvantages, composition and principle of operation of a semi-active radar system are considered in this article. Issues of technical realization of antennas and receivers of a semi-active radar system are investigated. An algorithm for signal processing in a semi-active radar system is proposed. For fulfilling the tasks of air surveillance and timely alerting of the air defense system to a higher degree of readiness when detecting the air threats and airborne intelligence assets of the enemy, currently in the area of the Operation of the Joint Forces the radar air surveillance system is deployed. This system is made up of traditional active radiolocation tools. The main disadvantage of such a system is its low survivability, which is due to the radiated signals, and, consequently, the ease of reconnaissance of radar positions by the enemy. Preservation of radar air surveillance system positions undetected and, consequently, the survivability of those radar systems is possible by supplementing them with the means of semi-active radar. Also, in the context of the so-called hybrid war in the area of Operation of the Joint Forces a ramified system of radio equipment continues to operate that can provide illumination field.

Keywords: radar, semi-active radar system, signal processing, target detection, principle of operation, antenna, receiver, transmitter. 